\title{
Effect of pregnancy, injection of oestradiol benzoate or hCG on steroid concentration and release by pig luteal cells
}

\author{
T. Wiesak \\ Department of Animal Physiology, University of Agriculture and Technology, Olsztyn 10-718, \\ Poland
}

\begin{abstract}
Summary. Corpora lutea were obtained from pig ovaries on Day 18 of pregnancy or pseudopregnancy. Pseudopregnancy was induced by the administration of oestradiol benzoate on Days 11-15 of the oestrous cycle or by the administration of hCG on Day 12. The luteal cells were prepared for morphometric analysis and investigation of steroid production in vitro by dispersion with $0 \cdot 25 \%$ trypsin. A blood sample from each sow was collected at slaughter for measurement of progesterone, oestradiol-17 $\beta$ and testosterone. The concentrations of these steroids were also estimated in luteal tissue and in the medium after incubation.

Progesterone concentration was significantly higher $(P<0.01)$ in luteal tissue and in plasma of pregnant than of pseudopregnant sows. Testosterone content of luteal tissue from all sows was 20 -fold higher than oestradiol, although plasma concentrations of these hormones were not different. The luteal cells from hCG-treated sows produced more progesterone $(P<0.01)$ in vitro than did those from the other groups. The luteal cells from oestradiol-treated sows generally released smaller amounts of steroids during incubation. Treatment with hCG increased the proportion of large luteal cells and decreased the proportion of small luteal cells. These results demonstrate that hCG or oestradiol benzoate injections altered the steroidogenic activity of luteal cells and that treatment with hCG was also associated with changes in the diameter of the luteal cells and thus in the ratio of small to large luteal cells.
\end{abstract}

Keywords: pregnancy; oestradiol benzoate; hCG; luteal cells; pig

\section{Introduction}

In the pig, as in many other mammals, the maintenance of early pregnancy depends on the secretion of progesterone by the corpora lutea beyond the time when luteal regression occurs in non-fertile oestrous cycles. Signals inhibiting luteolysis are undoubtedly produced during the maternal recognition of pregnancy. Several investigators have suggested that oestrogens are the signal from the pig conceptus for the maintenance of luteal function during pregnancy (Bazer et al., 1982, 1986; Flint et al., 1983).

The injection of human chorionic gonadotrophin (hCG) (Guthrie \& Rexroad, 1981; Guthrie \& Bolt, 1983; Guthrie \& Knudsen, 1984) or exogenous oestrogen (Gardner et al., 1963; Frank et al., 1977; Guthrie \& Rexroad, 1981; Ziecik et al., 1986) also delays luteolysis in cyclic pigs.

Guthrie \& Bolt (1983) and Guthrie \& Knudsen (1984) reported that the administration of hCG stimulated the development of large follicles and therefore that the luteotrophic effect of hCG may be mediated, in part, by the increase in follicular oestrogen production. Bazer et al. (1982) suggested that oestrogens exert a luteostatic action on the corpus luteum by maintaining its function. The higher oestrogen concentration in peripheral plasma of sows both in pregnancy 
(Robertson et al., 1978) and pseudopregnancy (Guthrie \& Bolt, 1983; Guthrie \& Knudsen, 1984) can presumably influence steroidogenesis by the corpus luteum.

In the present study, therefore, it was investigated whether oestradiol or hCG could affect steroidogenesis by pig luteal cells in vivo and in vitro or have any influence on luteal cell size.

\section{Materials and Methods}

Animals and blood samples. Sexually mature cross-bred sows, weighing $150-180 \mathrm{~kg}$, housed in the Farm of Commercial Pig Fattening were used. These 56 animals were assigned randomly to 3 treatment groups as follows:

In Group 1, pregnancy was induced by natural mating on a defined day of the oestrous cycle $(\mathrm{N}=20)$.

In Group 2, pseudopregnancy, i.e. prolonged maintenance of corpora lutea, was induced by intramuscular administration of $5 \mathrm{mg}$ oestradiol benzoate in $2 \mathrm{ml}$ corn oil on each of Days 10-15 of the oestrous cycle $(\mathrm{N}=22)$.

In Group 3, pseudopregnancy was induced by intramuscular injection of 1000 i.u. hCG (Biogonadyl, Laboratories of Sera and Vaccines, Lublin, Poland) on Day 12 of the oestrous cycle. The hCG was injected in $2 \mathrm{ml}$ of $0.9 \%$ (w/v) $\mathrm{NaCl}$ solution $(\mathrm{N}=14)$. Newly developed corpora lutea were observed in some pigs after the injection of ovulatory doses (1000 i.u.) of hCG, but the ovaries from these pigs were not used in the present study.

The day of mating and the first day of behavioural oestrus were designated as Day 0 . The sows were slaughtered on Day 18 of pregnancy or pseudopregnancy, respectively. One blood sample from each sow was collected during slaughter and the plasma stored at $-20^{\circ} \mathrm{C}$ until assayed.

Preparation of cell population and incubation. The ovaries were removed immediately after slaughter, placed in ice-cold phosphate-buffered saline (PBS, Laboratories of Sera and Vaccines) and transported to the laboratory. Pregnancy was confirmed by flushing the uterine horns for the presence of blastocysts. The mean number of corpora lutea per sow (12) did not differ between pregnant and pseudopregnant sows. Corpora lutea were carefully excised from the ovary and the surrounding tissues were completely removed. The luteal tissue was cut into small pieces and dissociated enzymically using a modification of the method described by Stouffer et al. (1976) in that a $0.25 \%$ solution of trypsin (Laboratories of Sera and Vaccines) was used instead of collagenase. After dispersion, cells were counted in a haemocytometer, viability was estimated using trypan blue $(1 \%)$ and the cells were resuspended to concentrations of $5 \times 10^{4}$ viable cell $/ \mathrm{ml}$ culture medium. Incubation of the cells in a final volume $1 \mathrm{ml}$ was carried out in Leighton tubes at $37^{\circ} \mathrm{C}$ for $6 \mathrm{~h}$. The incubations were static and were carried out in air. Culture medium consisted of Eagle's medium (Laboratories of Sera and Vaccines), which was supplemented with $2 \%$ human serum albumin fraction $\mathrm{V}$ (Laboratories of Sera and Vaccines), 50 i.u. penicillin/ml and $50 \mu \mathrm{g}$ streptomycin $/ \mathrm{ml}$. After incubation, the media and cells were frozen and stored at $-20^{\circ} \mathrm{C}$.

Determination of cell size. Cell diameters were measured using a micrometer-equipped ocular and the $\times 40$ objective. For each cell population from a given animal, 100-150 viable cell diameters were recorded.

Steroid extraction from luteal tissue. One of the corpora lutea from each ovary of all sows was stored at $-20^{\circ} \mathrm{C}$ until assayed for steroid content. The mean \pm s.e.m. weights of the corpora lutea were $301 \pm 80 \mathrm{mg}$ for Group I, $229 \pm 69 \mathrm{mg}$ for Group 2 and $340 \pm 16 \mathrm{mg}$ for Group 3. Thawed tissues were homogenized in $8 \mathrm{ml}$ buffer (PBS) containing Triton X-100 (Sigma, La Verpiliere Cedex, France) at a concentration of $0.05 \%$. Progesterone was extracted from the homogenate in a final volume of $20 \mathrm{ml}$ freshly distilled petroleum ether. Subsequently oestradiol$17 \beta$ and testosterone were extracted with $20 \mathrm{ml}$ diethyl ether. The extraction efficiency was monitored by the addition of $\left[{ }^{3} \mathrm{H}\right]$ progesterone (mean recovery, $89 \%$ ), $\left[{ }^{3} \mathrm{H}\right]$ oestradiol- $17 \beta$ (recovery $73 \%$ ) and $\left[{ }^{3} \mathrm{H}\right]$ testosterone (recovery $75 \%$ ). The extracts were evaporated under nitrogen and, thereafter, the residues were redissolved in a known volume of assay buffer (0-1 M-phosphate-buffered saline, $\mathrm{pH} 7 \cdot 0)$. Samples of the homogenates $(100 \mu \mathrm{l})$ were measured for protein content, according to the method of Lowry et al. (1951), using bovine serum albumin as the standard.

Steroid assay. The steroids in the plasma, culture medium and tissue extracts were measured by the radioimmunoassay procedures described by Abraham et al. (197I) for progesterone, by Hotchkiss et al. (1971) for oestradiol-17 $\beta$ and by Kotwica \& Williams (1982) for testosterone. Progesterone, oestradiol-17 $\beta$ and testosterone were extracted from plasma and incubation media, before assay, with petroleum ether and ethyl ether, respectively. Quality control samples were regularly introduced into each standard curve. The blank values run with each assay were below assay sensitivity. All the samples were assayed in triplicate. Radioactive steroids were obtained from the Radiochemical Centre (Amersham, Bucks, UK).

The cross-reactivity of the oestradiol antiserum with oestradiol benzoate was $83 \cdot 3 \%$.

Sensitivity of the assays, intra- and inter-assay variation were: for progesterone, $46 \cdot 91 \mathrm{pg} / \mathrm{tube}, 9 \cdot 10 \%$ and $14.52 \%$; for oestradiol- $17 \beta, 5.8 \mathrm{pg} /$ tube, $6.65 \%$ and $12.25 \%$; and for testosterone $8.12 \mathrm{pg} /$ tube, $8.91 \%$ and $14.05 \%$, respectively. Recoveries of progesterone, oestradiol-17 $\beta$ and testosterone after extraction from culture medium and plasma samples were $82 \cdot 88 \pm 2 \cdot 78 \%, 87 \cdot 18 \pm 1 \cdot 36 \%$ and $83.91 \pm 1 \cdot 42 \%$ respectively.

Statistical analysis. Data were analysed by split-plot analysis of variance followed by the Gill \& Hafs (1971) procedure. Duncan's Multiple Range test was used to compare means among the groups. 


\section{Results}

The results show that progesterone concentration in the fresh luteal tissue of pregnant sows (Group 1) was 3-fold higher than in that of pseudopregnant sows (Groups $2 \& 3)(P<0 \cdot 01$, Fig. 1). Similarly, progesterone concentration in the plasma was significantly higher in the pregnant than the pseudopregnant sows $(P<0 \cdot 01)$. The quantities of oestradiol-17 $\beta$ in the fresh luteal tissue and plasma of Group 2 sows were significantly different $(P<0.05, P<0.01)$ from those in Groups 1 and 3. Also, the testosterone content in luteal tissue of these sows was higher, although the plasma testosterone concentration was similar in all groups. Testosterone content in the luteal tissue of all the sows was approximately 20 -fold higher than that of oestradiol but this large difference did not occur in plasma.
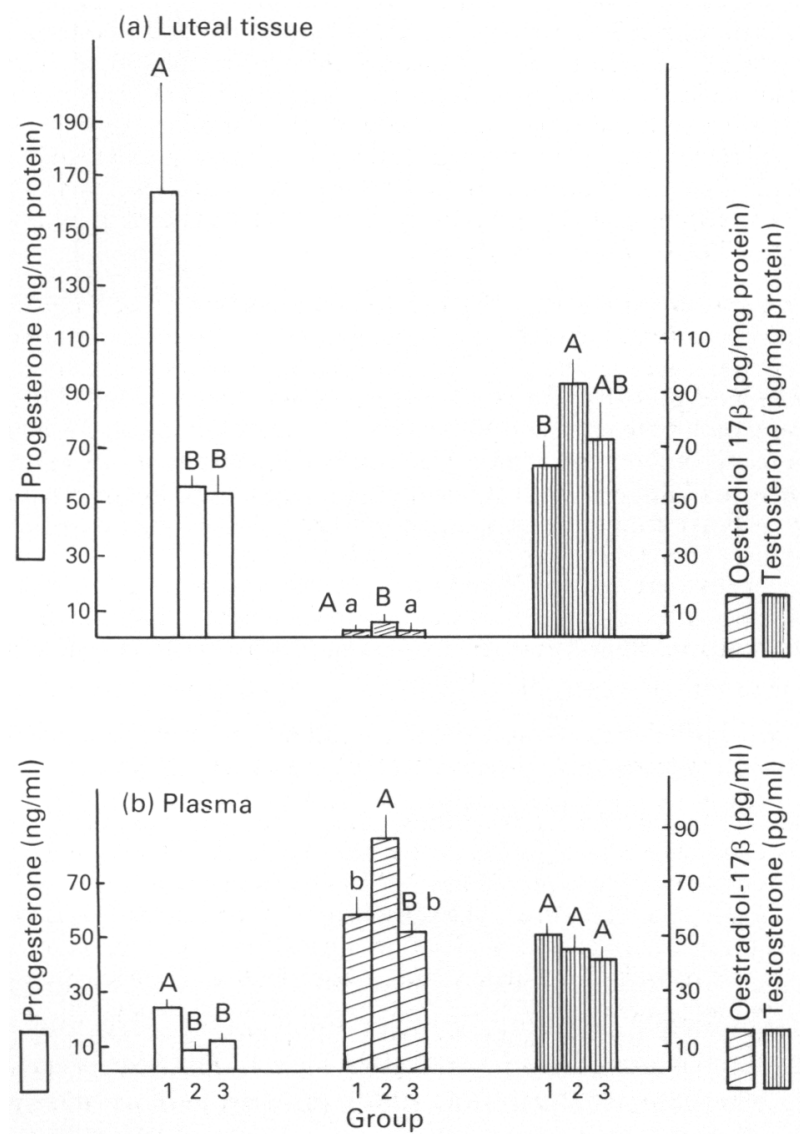

Fig. 1. Luteal (a) and plasma (b) concentrations of progesterone ( $\square$ ), oestradiol-17 ( $\mathscr{W}$ ) and testosterone (iil) of early pregnant and pseudopregnant sows. Each bar represents the mean\pm s.e.m. for 20 sows in Group 1 (pregnant), 21 in Group 2 (oestradiol benzoate treatment) and 13 in Group 3 (hCG treatment). Values with different superscript capital or small letters are significantly different $(P<0.01, P<0.05$, respectively).

The production of steroids in vitro by the luteal cells after $6 \mathrm{~h}$ of incubation is shown in Fig. 2 . The luteal cells obtained from Group 3 sows produced significantly more progesterone $(P<0.01)$ than did the cells of sows in Groups 1 and 2 and significantly more testosterone than the cells of Group 2 pigs $(P<0.05)$. The oestradiol-17 $\beta$ secretion was not significantly different between groups, although the luteal cells of Group 2 sows generally released fewer steroids during incubation. 


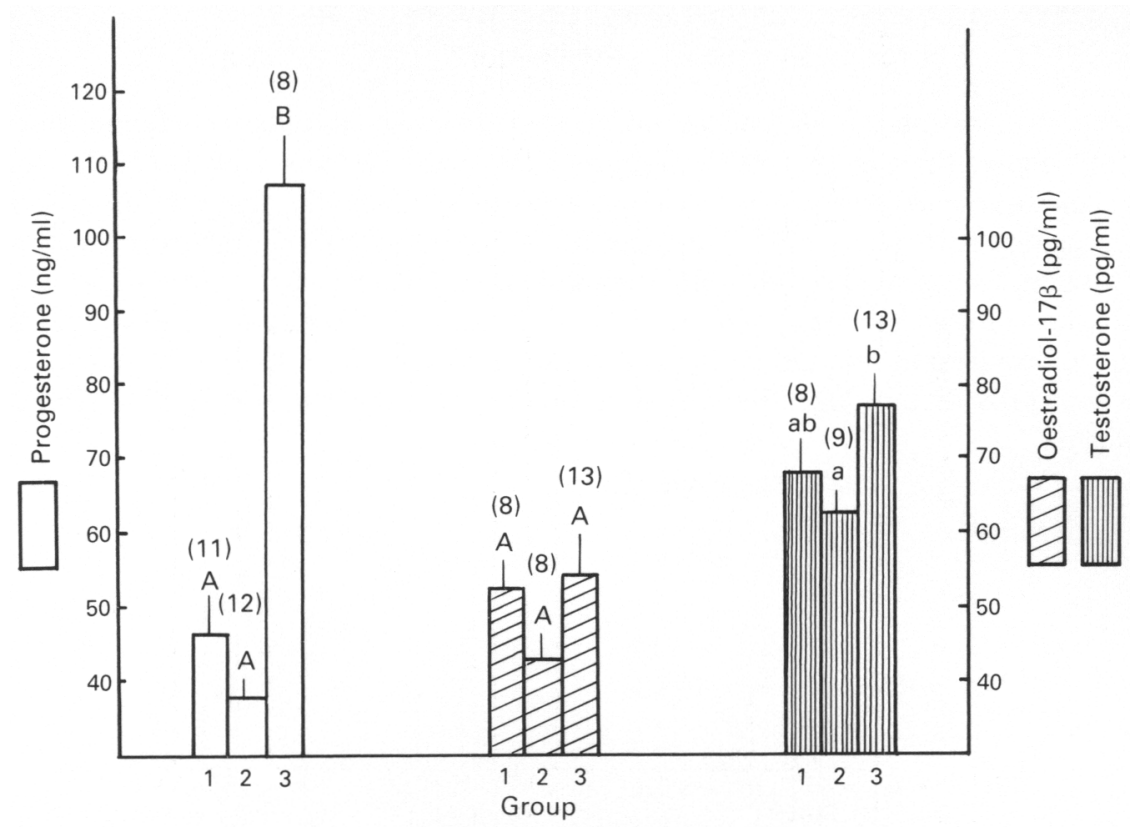

Fig. 2. Progesterone ( $\square$ ), oestradiol-17ß ( after $6 \mathrm{~h}$ incubation of luteal cells obtained from pregnant (Group 1) and pseudopregnant (Groups 2 and 3) sows. Values are mean \pm s.e.m. for the numbers of animals in each group indicated in parentheses. Values with different superscript capital or small letters are significantly different $(P<0.01, P<0.05$ respectively).

Treatment with oestradiol benzoate (Group 2) was not associated with any change in diameter or number of cells for small or large luteal cells (Fig. 3) compared to cells from pregnant sows (Group 1), whereas treatment with hCG (Group 3), increased the proportion of cells $>20 \mu \mathrm{m}$ in diameter and decreased the proportion of cells $<15 \mu \mathrm{m}(P<0.01)$, thereby significantly decreasing the ratio of small to large luteal cells $(P<0.01)$.

\section{Discussion}

The mechanism by which injections of oestrogens or hCG as well as blastocyst oestrogen prolong corpus luteum function in the pig is not fully understood at present. Previous studies have indicated that oestrogen administered before Day 10 and after Day 12 (Kidder et al., 1955; Gardner et al., 1963) or low doses of oestrogen given intramuscularly (Geisert et al., 1982) or through intrauterine infusion (Saunders et al., 1983) did not result in extended luteal maintenance beyond 30 days. Geisert et al. (1987) reported that oestradiol benzoate treatment $(5 \mathrm{mg})$ on Days 11 and $14-16$ was necessary for consistent luteal maintenance. The above results indicate that a prolonged exposure to high concentrations of oestrogen is required.

The results of the present study have demonstrated that progesterone content in the luteal tissue and plasma of oestradiol-treated sows was lower $(P<0.01)$ than in the pregnant pigs. Also, the luteal cells isolated from the corpora lutea of oestradiol-treated sows generally produced smaller amounts of steroids in vitro than did the luteal cell from the other sows, although this was not statistically significant. These results are compatible with the studies of Guthrie \& Rexroad (1981) and Ziecik et al. (1986), which indicated that plasma progesterone concentrations in oestradioltreated pigs were decreased. This suggests that pharmacological doses $(10-25 \mathrm{mg})$ of oestradiol suppressed the steroidogenic output of luteal cells. Nevertheless, a direct effect of oestradiol on 


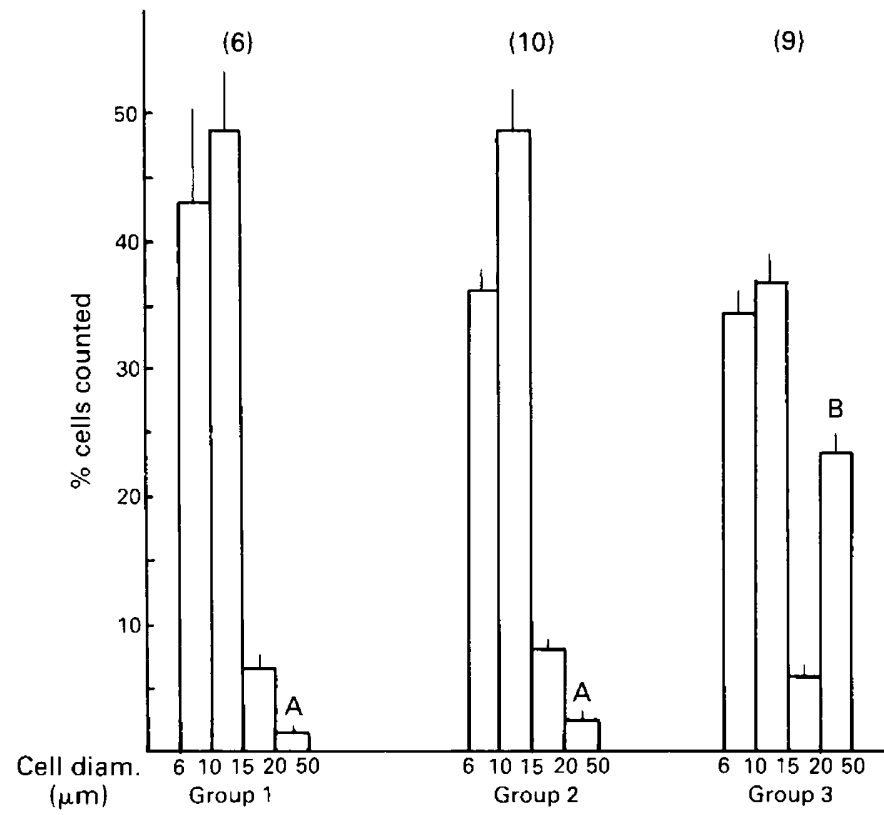

Fig. 3. The size distribution of luteal cells after dissociation of corpora lutea from pregnant (Group 1) and pseudopregnant (Groups 2 and 3) sows. Values are mean \pm s.e.m. for the number of sows indicated in parentheses. Values with different letters are different $(P<0.01)$.

testosterone (Grazul et al., 1986a) and progesterone (Watson \& Walker, 1978; Grazul et al., 1986b) synthesis in vitro or in vivo (Anderson et al., 1967) by pig luteal cells has not been observed, but oestrogen in high concentrations has been shown to inhibit LH-stimulated follicular androgen production in the rat in vivo (Leung \& Armstrong, 1980), and in pig granulosa and theca cells in vitro (Veldhuis, 1985; Hunter \& Armstrong, 1987). Furthermore, Garverick et al. (1982) concluded that oestrogens may have a direct effect on the corpus luteum in the pig, since oestradiol-17 $\beta$ raised luteal LH receptor levels. However, Ziecik et al. (1986) suggested that the reduction in progesterone secretion during pseudopregnancy in the oestradiol-treated pig seemed to be caused by a partial blockade of the synthesis of this hormone, probably due to lower adenylate cyclase activity.

An indirect effect of exogenous oestradiol on steroid production by luteal cells of oestradioltreated pigs cannot be excluded. Ziecik et al. (1986) showed that the concentration of prolactin in oestradiol-treated pigs was 7-20 times higher than in pregnant pigs and therefore this elevated prolactin level may have suppressed luteal steroidogenesis (McNeilly et al., 1982; Przala et al., $1984 \mathrm{a}, \mathrm{b}$ ). The high oestradiol- $17 \beta$ content in the plasma and luteal tissue of oestradiol-treated sows in the present study is likely to be a consequence of oestradiol binding by the oestradiol antiserum (cross-reactivity $=83 \%$ ).

The high progesterone production in vitro by luteal cells from the hCG-treated sows can be explained by: (1) extremely high stimulation in vivo (ovulatory doses of hCG were given on Day 12, which corresponds with the time when corpora lutea possess the greatest number of $\mathrm{LH} / \mathrm{hCG}$ receptors during the oestrous cycle) (Ziecik et al., 1980; Rao \& Edgerton, 1984) and (2) many large luteal cells were present in the dissociated cell population $(23 \cdot 11 \%$ compared with $1.55 \%$ for pregnant and $2.55 \%$ for oestradiol-treated sows) and it has been shown that the large luteal cells have a higher rate of basal progesterone production than do small luteal cells (Rodgers et al., 1983; Niswender et al., 1985). In addition, the lack of elevated progesterone concentration in the luteal tissue of hCG-treated sows seems to indicate an increased release of progesterone into the peripheral plasma compared to the pregnant pig. This suggestion is consistent with the study of Guthrie \& Rexroad (1981), who reported that an injection of hCG on Day 12 caused an increase in 
progesterone in plasma up to Day 17 whereafter progesterone concentration remained slightly higher than in pregnant pigs. Although the results of progesterone content in plasma in the present experiment did not show this increase, this apparent discrepancy may be due to the fact that in the present study only one sample of plasma for progesterone estimation was taken from each pig at slaughter.

All the corpora lutea examined contained significantly more testosterone than oestradiol-17 $\beta$ ( $\sim 20$-fold $)$, whereas the testosterone and oestradiol-17 $\beta$ concentration in the plasma of these sows were not different. Also, the luteal cells in vitro released more testosterone than oestradiol-17 $\beta$. Similar observations have been made for the cow (Lukaszewska, 1980), rabbit (Hilliard et al., 1974), rat (Sridaran et al., 1981), pregnant pig (Grazul et al., 1987) and non-pregnant pig (Przala et al., 1984a). The high testosterone content of the luteal tissue may indicate that testosterone is stored in case it is required to synthesize a large amount of oestrogens by the corpus luteum (Lemon \& Loir, 1977; Watson \& Patek, 1979; Przala et al., 1984a), which can have a local effect by increasing progesterone secretion (Gregoraszczuk, 1983). On the other hand it seems more likely that oestrogens are released into the plasma or changed into oestrone (Robertson et al., 1978) rather than accumulated by the corpus luteum during early pregnancy.

Microscopic examination of the cell suspensions from sows in all 3 groups provided evidence for the concept that small luteal cells can develop into large luteal cells in response to LH or hCG (Alila \& Hansel, 1984). Although the interpretation of the morphometric analysis is based on dissociated cell preparations and only the diameter of the cells was measured, treatment with hCG on Day 12 was associated with an increase in the proportion of luteal cells $>20 \mu \mathrm{m}$ in diameter and a decrease in the proportion of cells $<15 \mu \mathrm{m}$ and thus the ratio of small to large luteal cells was decreased $(P<0.01)$. These observations are in accordance with the data for the sheep corpus luteum (Farin et al., 1988).

In conclusion, this study has demonstrated that multiple injections of oestradiol or a single injection of hCG during the mid-luteal phase of the oestrous cycle can maintain corpus luteum function. Furthermore, exogenous oestrogen suppresses but hCG enhances steroidogenesis by the luteal cells and exogenous hCG can alter the number and size distribution of luteal cells in the corpora lutea. This suggests that the corpora lutea of early pregnant, oestradiol- or hCG-treated sows differ from each other and that induction of prolonged luteal function during pregnancy or pseudopregnancy requires further investigation.

I thank Miss B. Szwarc for technical assistance; Professor Dr R. Stupnicki (Institute of Animal Physiology and Nutrition of the Polish Academy of Sciences, Jablonna near Warsaw) for the gift of the progesterone antiserum; the Institute of Pharmacology Polish Academy of Sciences, Cracow for oestradiol and testosterone antisera; Dr M. G. Hunter for help in preparing the manuscript; and Mrs M. Newman for typing the manuscript.

This work was supported by the grant of Ministry of Science and Higher Education (Project MR-11-10).

\section{References}

Abraham, G.E., Swerdloff, R., Tulchinsky, D. \& Odell, W.D. (1971) Radioimmunoassay of plasma progesterone. J. clin. Endocr. Metab. 32, 619-624.

Alila, H.W. \& Hansel, W. (1984) Origin of different cell types in the bovine corpus luteum as characterized by specific monoclonal antibodies. Biol. Reprod. 31, 1015-1025.

Anderson, L.L., Dyck, G.W., Mori, H., Henricks, D.M. \& Melampy, R.M. (1967) Ovarian function in pigs following hypophysial stalk transection or hypophysectomy. Am. J. Physiol. 212, 1188-1194.
Bazer, F.W., Geisert, R.D., Thatcher, W.W. \& Roberts, R.M. (1982) The establishment and maintenance of pregnancy. In Control of Pig Reproduction, pp. 227-252, Eds D. J. A. Cole \& G. R. Foxcroft. Butterworths, London.

Bazer, F.W., Vallet, J.L., Roberts, R.M., Sharp, D.C. \& Thatcher, W.W. (1986) Role of conceptus secretory products in establishment of pregnancy. J. Reprod. Fert. 76, 841-850.

Farin, C.E, Moeller, C.L., Mayan, H., Gamboni, F., Sawyer, H.R. \& Niswender, G.D. (1988) Effect of 
luteinizing hormone and human chorionic gonadotropin on cell populations in the ovine corpus luteum. Biol. Reprod. 38, 413-421.

Flint, A.P.F., Burton, R.D., Gadsby, J.E., Heap, R.B. \& Sheldrick, E.L. (1983) Embryonic steroid synthesis and luteal oxytocin production: controlling mechanisms for the maternal recognition of pregnancy. $J$. Steroid Biochem. 19, 973-978.

Frank, M.F., Bazer, F.W., Thatcher, W.W. \& Wilcox, C.J. (1977) A study of prostaglandin $F_{2 a}$ as the luteolysin in swine. III. Effect of estradiol valerate on prostaglandin $F$, progestins, estrone and estradiol concentrations in the utero-ovarian vein on nonpregnant gilts. Prostaglandins 14, 1183-1196.

Gardner, M.L., First, N.L. \& Casida, L.E. (1963) Effect of exogenous estrogens on corpus luteum maintenance in gilt. J. Anim. Sci. 22, 132-134.

Garverick, H.A., Polge, C. \& Flint, A.P.F. (1982) Oestradiol administration raises luteal $\mathrm{LH}$ receptor levels in intact and hysterectomized pigs. $J$. Reprod. Fert. 66, 371-377.

Geisert, R.D., Renegar, R.H., Thatcher, W.W., Roberts, R.M. \& Bazer, F.W. (1982) Establishment of pregnancy in the pig. II. Endometrial secretory response to estradiol valerate administered on day 1 I of the estrous cycle. Biol. Reprod. 27, 957-965.

Geisert, R.D., Zavy, M.T., Wettemann, R.P. \& Biggers, B.G. (1987) Length of pseudopregnancy and pattern of uterine protein release as influenced by time and duration of oestrogen administration in the pig. $J$. Reprod. Fert. 79, 163-172.

Gill, J.L. \& Hafs, H.D. (1971) Analysis of repeated measurements of animals. J. Anim. Sci. 32, 331-336.

Grazul, A., Przala, J., Wiesak, T. \& Muszynska, A. (1986a) Estradiol $17 \beta$ influence on testosterone production of luteal cells from early pregnant, oestradiol benzoate-treated on human chorionic gonadotropin treated sows in vitro. Acta vet. hung. 34, 263-269.

Grazul, A., Przala, J., Wiesak, T. \& Muszynska, A. (1986b) Effect of estradiol-17 $\beta$ and luteinizing hormone on progesterone secretion by luteal cells from early pregnant, estradiol benzoate-treated and human chorionic gonadotropin-treated sows. Expl clin. Endocrinol. 87, 239-246.

Grazul, A., Przala, J., Wiesak, T. \& Muszynska, A. (1987) Action of GnRH on steroid secretion by luteal cells of cyclic and early pregnant sows in vitro. Acta physiol. hung. 69, 203-210.

Gregoraszczuk, E. (1983) Steroid hormone release in cultures of pig corpus luteum and granulosa cells: effect of LH, hCG, PRL and estradiol. Endocr. exp. 19, 304-311.

Guthrie, H.D. \& Bolt, D.J. (1983) Changes in plasma estrogen, luteinizing hormone, follicle-stimulating hormone and 13,14-dihydro-15-keto-prostaglandin $F_{2 a}$ during blockade of luteolysis in pigs after human chorionic gonadotropin treatment. J. Anim. Sci. 57, 993-1000.

Guthrie, H.D. \& Knudsen, J.E. (1984) Follicular growth and production of estrogen and progesterone after injection of gilts with human chorionic gonadotropin on day 12 of the estrous cycle. J. Anim. Sci. 59, 1295-1302.

Guthrie, H.D. \& Rexroad, C.E., Jr (1981) Endometrial prostaglandin $F$ release in vitro and plasma 13,14 dihydro-15-keto-prostaglandin $F_{2} \alpha$ in pigs with luteolysis blocked by pregnancy, estradiol benzoate or human chorionic gonadotropin. J. Anim. Sci. 52 , $330-339$.

Hilliard, J., Scaramuzzi, R.J., Pang, C.H., Penardi, R. \& Sawyer, C.H. (1974) Testosterone secretion by rabbit ovary in vitro. Endocrinology 94, 267-271.

Hotchkiss, J., Atkinson, L.E. \& Knobil, E. (1971) Time course of serum estrogen and luteinizing hormone (LH) concentration during the menstrual cycle of the rhesus monkey. Endocrinology 89, 177-183.

Hunter, M.G. \& Armstrong, D.T. (1987) Oestrogens inhibit steroid production by dispersed porcine thecal cells. Molec. cell. Endocrinol. 50, 165-170.

Kidder, H.E., Casida, L.E. \& Grummer, R.H. (1955) Some effects of estrogen injections on the estrual cycle of gilts. J. Anim. Sci. 14, 470474.

Kotwica, J. \& Williams, G.L. (1982) Relationship of plasma testosterone concentrations to pituitary ovarian hormone secretion during the bovine estrous cycle and the effects of testosterone propionate administered during luteal regression. Biol. Reprod. 27, $790-801$

Lemon, M. \& Loir, M. (1977) Steroid release in vitro by two luteal cell types in the corpus luteum of the pregnant sow. $J$. Endocr. 72, 351--359.

Leung, P.C.K. \& Armstrong, D.T. (1980) Interactions of steroids and gonadotrophins in the control of steroidogenesis in the ovarian follicle. Ann. Rev. Physiol. 42, $71-82$.

Lowry, O.H., Rosebrough, N.J., Farr, A.L. \& Randall, R.J. (1951) Protein measurement with the folin phenol reagent. J. biol. Chem. 193, 265-275.

Lukaszewska, J. (1980) Czynniki luteolityczne i luteotropowe u krowy w cyklu jajnikowym i wczesnej ciazy. Zesz. nauk. ART Olszt. 20, 10-52.

McNeilly, A.S., Glasier, A., Jonassen, J. \& Howie, P.W. (1982) Evidence for direct inhibition of ovarian function by prolactin. J. Reprod. Fert. 65, 559-569.

Niswender, G.D., Schwall, R.H., Fitz, T.A., Farin, C.E. \& Sawyer, H.R. (1985) Regulation of luteal function in domestic ruminants: new concepts. Recent Prog. Horm. Res. 41, 101-151.

Przala, J., Wiesak, T., Grazul, A. \& Cieplinska, E. (1984a) The effect of prolactin on estradiol-17 $\beta$ and testosterone plus $5 \alpha$-dihydotestosterone secretion by porcine luteal cells in vitro. Expl clin. Endocrinol. 83, 343-348.

Przala, J., Grazul, A. \& Wiesak, T. (1984b) The influence of prolactin (PRL) on progesterone secretion by porcine luteal cells in vitro. Anim. Reprod. Sci. 7, 351362.

Rao, Ch. O. \& Edgerton, L.A. (1984) Dissimilarity of corpora lutea within the same ovaries or those from right and left ovaries of pigs during the oestrous cycle. $J$. Reprod. Fert. 70, 61-66.

Robertson, H.A., King, G.J. \& Dyck, G.W. (1978) The appearance of oestrone sulphate in the peripheral plasma of the pig early in pregnancy. J. Reprod. Fert. 52, 337-338.

Rodgers, R.J., O'Shea, J.D. \& Findlay, J.K. (1983) Progesterone production in vitro by small and large ovine luteal cells. J. Reprod. Fert. 69, 113-124.

Saunders, M.J., Edgerton, L.A., Kagan, J.M., Stahly, T.S. \& Cromwell, G.L. (1983) Comparison of intra- 
uterine and subcutaneous sites of estrogen injection for luteal maintenance in swine. J. Anim. Sci. 57, 146-149.

Sridaran, R., Basuray, R. \& Gibori, G. (1981) Source and regulation of testosterone secretion in pregnant and pseudopregnant rats. Endocrinology 108, 855-861.

Stouffer, R.L., Nixon, W.E., Gulyas, B.J., Johnson, D.K. \& Hodgen, G.D. (1976) In vitro evaluation of corpus luteum function of cycling and pregnant rhesus monkeys: progesterone production by dispersed luteal cells. Steroids 27, 543-551.

Veldhuis, J.D. (1985) Bipotential actions of estrogen on progesterone biosynthesis by ovarian cells. I. Relation of estradiol's inhibitory actions to cholesterol and progestin metabolism in cultured swine granulosa cells. Endocrinology 116, 1818-1825.
Watson, J. \& Patek, C.E. (1979) Steroid and prostaglandin secretion by the corpus luteum, endometrium and embryos of cyclic and pregnant pigs. J. Endocr. 82, 425-428.

Watson, J. \& Walker, F.M.M. (1978) Progesterone secretion by the corpus luteum of the early pregnant pig during superfusion in vitro with PGF-2 $\alpha, \mathrm{LH}$ and estradiol. J. Reprod. Fert. 52, 209-212.

Ziecik, A., Shaw, H.J. \& Flint, A.P.F. (1980) Luteal LH receptors during the oestrous cycle and early pregnancy in the pig. J. Reprod. Fert. 60, 129-137.

Ziecik, A., Doboszyniska, T. \& Dusza, L. (1986) Concentrations of $\mathbf{L H}$, prolactin and progesterone in early pregnant and oestradiol-treated pigs. Anim. Reprod. Sci. 10, 215-224.

Received 30 August 1988 